\title{
DIFERENSIASI ORGAN PENCERNAAN LARVA KERAPU BEBEK TURUNAN KE-3 (F-3) DAN BEBERAPA AKTIVITAS ENZIM YANG TERKAIT
}

\author{
Wawan Andriyanto dan Ahmad Muzaki \\ Balai Besar Penelitian dan Pengembangan Budidaya Laut \\ Jl. Br. Gondol Kec. Gerokgak Kab. Buleleng, Kotak Pos 140, Singaraja, Bali 81101 \\ E-mail:wa2n.rimgdl@gmail.com
}

(Naskah diterima: 17 Oktober 2012; Disetujui publikasi: 4 Februari 2013)

\begin{abstract}
ABSTRAK
Pengamatan perkembangan diferensiasi saluran pencernaan larva ikan kerapu bebek F-3 hasil pembenihan induk generasi F-2 telah dilakukan melalui serangkaian pemeliharaan dari umur satu hari setelah menetas (HSM) sampai dengan 40 HSM. Sampel larva diambil setiap hari dari 1 HSM sampai dengan 10 HSM dan dilanjutkan interval tiga hari sampai umur 40 hari. Pakan alami diberikan sesuai dengan standar operasional prosedur (SOP) perbenihan kerapu namun tidak diberikan pengkayaan apapun dalam pakan alaminya. Sampel dianalisis secara histologi dengan staining menggunakan HE dan dianalisis pula aktivitas tripsin dan cimotripsinnya menggunakan teknik enzim assay. Fase yolk sac sampai dengan umur $10 \mathrm{HSM}$, perkembangan (diferensiasi) saluran pencernaan berkembang sangat pesat. Pada fase ini organ pencernaan larva sudah terbagi dari mulut, esophagus, perut, usus, dan anus namun belum sempurna. Aktivitas tripsin dan cimotripsin sudah terdeteksi pada fase tersebut. Pada umur 13 HSM sampai dengan memasuki fase yuwana (28 HSM) organ pencernaan terutama perut dan usus mulai berkembang. Fase yuwana tercapai lebih lambat daripada larva kerapu bebek dari penelitian sebelumnya yang menggunakan larva turunan F-1 yang diberi pengkayaan pakan, hal ini ditunjukkan dengan terbentuknya gastric gland dan pyloric caeca sebagai indikator saluran pencernaan berfungsi dengan baik baru terjadi pada umur 28 HSM. Informasi yang bisa digaris bawahi dari pengamatan ini adalah bahwa hasil pembenihan kerapu bebek turunan ke-3 sudah bisa dilakukan namun perkembangan organ pencernaan yang cenderung lebih lambat dari turunan F-1-nya. Hal ini kemungkinan disebabkan oleh faktor pengkayaan pakan atau hal lain yang perlu diamati lebih lanjut.
\end{abstract}

KATA KUNCI: larva kerapu bebek, turunan ke-3, organ pencernaan, enzim

ABSTRACT: Digestive organ differentiation of the third generation (F-3) humpback grouper larvae and some related enzyme activity. By: Wawan Andriyanto and Ahmad Muzaki

Observation on the development of the digestive tract differentiation of F-3 humpback grouper larvae from $1^{\text {st }}$ day after hatching $(D A H)$ until $40^{\text {th }} D A H$ has done. The sampel was collected daily from $1^{\text {st }} D A H$ until $10^{\text {th }} D A H$ and every 3 days from $13^{\text {th }} D A H$ until $40^{\text {th }} \mathrm{DAH}$. Natural food was given in accordance with procedure of grouper seed production without enrichment process. Samples were analyzed histologically and stained using HE. Tripsin and chymotripsin activity were analyzed using enzyme assay technique. Yolk sac stage until $10^{\text {th }} \mathrm{DAH}$, differentiation of the digestive tract was grown very rapidly. Larval digestive organ has divided into the mouth, esophagus, stomach, colon, and rectum, but still not completely develop. Trypsin and chymotrypsin 
activity was detected in this stage. The digestive organs especially the stomach and intestines begin to develop on $13^{\text {th }}$ DAH until juvenile stage $\left(28^{\text {th }} D A H\right)$. Juvenile stage in this study was reached slower from a previous study were used F-1 humpback grouper larvae fed with enrichment food. The result shown the formation of gastric glands and pyloric caeca occur on $28^{\text {th }} \mathrm{DAH}$ as indicators of well-functioning digestive tract. The information can be highlighted from these observations is that the seed production of F-3 humpback grouper larvae was succesfuly, but the development of the digestive organs that tend to be slower than F-1. This is probably caused by the enrichment factor of the feed or anything else that needs to be observed further.

\section{KEYWORDS: humpback grouper larvae, F-3, digestive tract, enzyme}

\section{PENDAHULUAN}

Budidaya kerapu bebek (Cromileptes altivelis) di Indonesia mulai berkembang pada awal tahun 2000. Calon induk yang dipergunakan di pembenihan pada awalnya hasil penangkapan dari alam sehingga ketersediaannya di alam pun semakin lama semakin berkurang. Oleh karena itu, pengembangan budidaya kerapu selain menghasilkan benih juga dilakukan upaya untuk menghasilkan calon calon induk kerapu bebek turunan 1 (F-1) (Giri, et al., 2006; Trijoko et al., 2006; Trijoko, 2007; 2008, Tridjoko et al., 2008) dan turunan ke-2 (F-2) (Tridjoko, 2010a; 2010b; Tridjoko \& Gunawan, 2010; Tridjoko \& Haryanti, 2010 ; Tridjoko \& Priono, 2011 ). Pembenihan turunan ke-2 (F-2) yang dilakukan sekitar tahun 2008-2009 khususnya di Balai Besar Penelitian dan Pengembangan Budidaya Laut, Gondol-Bali telah dihasilkan produksi telur. Keberhasilan dalam penyediaan induk F-2 tersebut memberikan harapan keberlangsungan usaha budidaya kerapu bebek tetap prospektif. Dari faktor ketersediaan induk keberhasilan ini dapat menekan risiko kepunahan spesies kerapu bebek di alam sehingga budidaya menjadi salah satu faktor yang sangat vital untuk ketahanan pangan nasional dan upaya konservasi alam di masa mendatang. Keberhasilan mendapatkan calon induk kerapu bebek tentunya juga harus diikuti keberhasilan dalam pemijahan dan perbenihannya. Benih kerapu bebek turunan F-0 dan F-1 selama ini telah berkembang dalam budidaya di tingkat pembudidaya laut. Penelitian tentang faktor biologi, nutrisi, lingkungan, penyakit, dan pakan telah banyak dilakukan untuk benih F-0 dan F-1. Namun untuk turunan F-3-nya masih belum banyak diamati. Studi perkembangan pencernaan larva kerapu bebek sebelumnya telah diketahui bahwa pencernaan larva kerapu bebek mulai fungsional sekitar umur 25 HSM (Munafi et al., 2011).

Stadia larva merupakan salah satu faktor kritis dalam perbenihan kerapu bebek, sehingga sampai saat inipun banyak kendala dalam peningkatan sintasan dan pertumbuhannya. Fase kritis terjadi sebagian besar pada usia 1 hari setelah menetas sampai 40 hari. Angka kematian tinggi pada tahap ini disebabkan oleh faktor makanan dan penyakit. Larva kerapu sangat sensitif bahkan untuk gangguan mekanis yang minimal khususnya selama metamorfosis. Pada tahap penetasan, larva kerapu kecil dan rapuh dengan cadangan makanan dari yolk sac (Ordonio-Aguilar, 1995). Kombinasi faktor ini dianggap menjadi penyebab mendasar dari kematian yang tinggi dan pertumbuhan yang lambat selama pemeliharaan larva (Kohno et al., 1997). Oleh karena itu, studi tentang fisiologi larva ikan dan kebutuhan nutrisi khususnya spesies kerapu harus memberikan informasi untuk memecahkan beberapa masalah ini (Govoni et al., 1986; Segner et al., 1993). Studi tentang diferensiasi saluran pencernaan larva ikan harus dilakukan sebagai langkah pertama karena sebagian besar fungsi fisiologis didasarkan pada perkembangan organ (Hamlin et al., 2000; Govoni, 2004).

Struktur morfologi pada saluran pencernaan larva ikan lebih kompleks karena disertai oleh adanya aktivitas enzim (Timeyko \& Novikov, 1987). Spesies ikan yang berbeda memiliki pencernaan yang berbeda serta kemampuan mencerna yang berbeda karena perbedaan dalam struktur saluran pencernaan mereka dan dalam cara mereka makan (Eusebio et al., 2004). Aktivitas enzim pencernaan telah digunakan untuk mengevaluasi kemampuan mencerna larva ikan pencernaan selama pertumbuhan (Segner et al., 1993; Segner et al., 1994; Zambonino-Infante \& Cahu, 2001; 
Ribeiro et al., 1999), dan aktivitas enzim pencernaan dapat menunjukkan kebutuhan nutrisi yang berbeda (Buddington, 1985). Pada tahap awal kehidupan, enzim pankreas seperti tripsin, amylase, dan lipase, sangat penting untuk pencernaan larva, karena pada tahap ini saluran pencernaan masih belum fungsional dalam beberapa spesies ikan (Zambonino-Infante \& Cahu, 2001). Enzim proteolitik yang digunakan sebagai indikator kondisi gizi, dan terutama tripsin telah terbukti menjadi indikator penyerapan makanan yang tepat (Pedersen \& Hjelmeland, 1988; Ueberschär, 1995). Kematian yang tinggi yang terjadi pada stadia awal larva berhubungan dengan faktor makanan setelah habis persediaan makanan dari yolk sac (Kohno et al., 1997). Larva E. coioides menunjukkan aktivitas enzim pencernaan rendah selama 10 hari setelah menetas (Eusebio et al., 2004; McBride, 2004). Tripsin merupakan endoproteinase telah dipilih sebagai enzim indikator, karena terhubung langsung ke metabolisme protein dan terdapat pada stadia awal larva ikan. Studi enzimatik, merupakan langkah awal untuk identifikasi serta sumber informasi yang penting untuk menentukan waktu ketika sistem pencernaan larva secara fungsional siap untuk mencerna dan mengasimilasi pakan buatan (Segner et al., 1993; Sarasquete \& Yufera, 1995).

Keberhasilan pengembangan sistem pencernaan sangat penting untuk sintasan dan pertumbuhan larva ikan karena sistem pencernaan yang efisien memungkinkan ikan untuk menangkap, mencerna, dan menyerap makanan (Kjorsvik et al., 2004). Meskipun secara morfologis larva mampu menangkap makanan di awal makan (Segner et al., 1994; Bisbal \& Bengtson, 1995), namun sistem pencernaan membutuhkan serangkaian perubahan perkembangan sebelum berfungsi penuh (Govoni et al., 1986; Canino \& Bailey, 1995). Pengetahuan tentang perkembangan struktural dari sistem pencernaan sangat penting untuk memahami fisiologi pencernaan dan menentukan waktu yang tepat untuk larva ikan dapat memanfaatkan pakan secara optimal (Watanabe \& Kiron, 1994; Baglole et al., 1997; Cahu \& Zambonino-Infante, 2001). Tujuan dari penelitian ini untuk mengamati diferensiasi saluran pencernaan selama metamorfosis dari larva menjadi yuwana dan aktivitas tripsin dan cimotrypsin untuk memahami urutan perkembangan organ dan faktor enzim yang ada khususnya untuk benih kerapu bebek turunan ke-3.

\section{BAHAN DAN METODE}

Telur berasal dari pemijahan induk generasi ke-2 (F-2) dikumpulkan dengan menggunakan kolektor telur ukuran $400(\mu \mathrm{m})$. Telur kemudian dipindahkan ke bak fiber ukuran $100 \mathrm{~L}$ untuk diinkubasi. Telur yang tidak terbuahi dibuang dengan cara disipon. Telur yang dibuahi ditebar ke dalam bak ukuran $1.000 \mathrm{~L}$ dan diberi aerasi. Proses penebaran dan pemeliharaan larva (pemberian pakan alami sampai pakan buatan dan manajemen pergantian air) mengikuti SOP perbenihan kerapu yang telah ada di BBPPBL Gondol. Hal yang tidak dilakukan adalah pengkayaan pakan alami/buatan agar larva yang hidup dikondisikan normal. Larva dipelihara dari menetas sampai dengan 40 hari setelah menetas (HSM), karena diasumsikan pada umur 40 HSM larva telah mencapai stadia yuwana. Untuk pengamatan diferensiasi organ pencernaannya, 10 sampel diambil secara sampling (acak) setiap hari dari 1 HSM sampai 10 HSM, kemudian setiap tiga hari dari 13 HSM sampai dengan 40 HSM. Setelah itu, difiksasi menggunakan larutan bouin's selama lebih kurang enam jam. Sampel kemudian dipindah ke dalam larutan $70 \%$ alkohol sebelum "tissue processing". Sampel didehidrasi dalam ethanol dengan kepekatan berbeda dan xylene untuk memastikan larutan wax masuk ke dalam jaringan. Setelah proses itu selesai, dilakukan proses "embedding" dengan paraffin wax. Sampel kemudian dipotong tipis dengan ketebalan sekitar $5 \mu \mathrm{m}$ dan hasil potongan ditempatkan dalam "slide" yang telah diberi kode sampel. Kemudian potongan histologi dalam slide tersebut dikeringkan selama semalam untuk kemudian di-staining (diwarnai) dengan haematoxylene dan eosine (HE). Semua prosedur tersebut mengacu kepada teknik histologi seperti yang dilakukan oleh Drury \& Wallington (1967), dan Kiernan (1990). Hasil preparat histologi yang telah di-staining tersebut kemudian diamati dengan mikroskop yang dilengkapi dengan foto yang terintegrasi dengan komputer untuk mendapatkan perbesaran dan ukurannya.

Untuk pengamatan enzim, sediaan sampel diawetkan menggunakan nitrogen cair selama 30 detik dan kemudian disimpan dalam penyejuk dengan suhu $-80^{\circ} \mathrm{C}$. Larva kemudian dihomogenisasi dalam Tris-HCL dingin menggunakan "hand held glass homogenizer". Homogenat kemudian disentrifugasi pada suhu $4^{\circ} \mathrm{C}$ dengan kecepatan $10.000 \mathrm{rpm}$ 
selama 15 menit. Endapan dan supernatan dipisahkan, kemudian supernatan disimpan pada suhu $-20^{\circ} \mathrm{C}$ sebelum dianalisis. Aktivitas tripsin dan cimotripsin diukur dengan menggunakan $\mathrm{N}$ - $\alpha$-benzoyl-DL-Arginine-p-nitroanilide (BAPNA) dan Suc-Ala-Ala-Pro-Phe-pnitroanalidine (SAPNA) sebagai substrat masingmasing enzim. Perubahan absorbansi dilihat dalam mode kinetik selama 3 menit pada 410 nm (Erlanger et al., 1961). Aktivitas enzim (mU/ $\mathrm{mg}$ protein) dihitung dengan persamaan:

Activity units $=[($ Abs $410 \mathrm{~nm} / \mathrm{min}) \times 1.000 \times$ Volume of reaction mixture $] / 8.800 \times \mathrm{mg}$

di mana:

$8.800=$ Koefisien molar dari para-nitroanilide $\mathrm{mg}=$ Bobot jaringan dalam larutan enzim Analisis data dilakukan secara deskriptif (grafik dan gambar)

\section{HASIL DAN BAHASAN}

Dari pengamatan histologis, pada hari pertama setelah menetas (1 HSM), rongga mulut, dan kerongkongan belum bisa dibedakan dan masih tertutup (Gambar 1a). Satu lapisan epitel skuamosa terbentuk pada 2 HSM sebelum mulut terbuka. Mulut mulai terbuka pada 2 HSM ditandai dengan mulai tampak seperti katup berbentuk oral pada bagian depan rongga mulut (Gambar 1b). Pada umur 3 HSM, mulut terbuka, dan lapisan epitel skuamosa tampak bertingkat (Gambar 1c). Umur 4 HSM, gigi atas dan gigi bawah mulai terlihat di bagian anterior mulut (Gambar 1d). Taste buds (organ perasa) terlihat pertama kali pada 5 HSM (Gambar 1e) (arrow). Sedangkan gigigigi faring terbentuk pada 8 HSM dalam tekak (Gambar 1f) (arrow), dan kemudian berkembang sejalan dengan perkembangan larva.
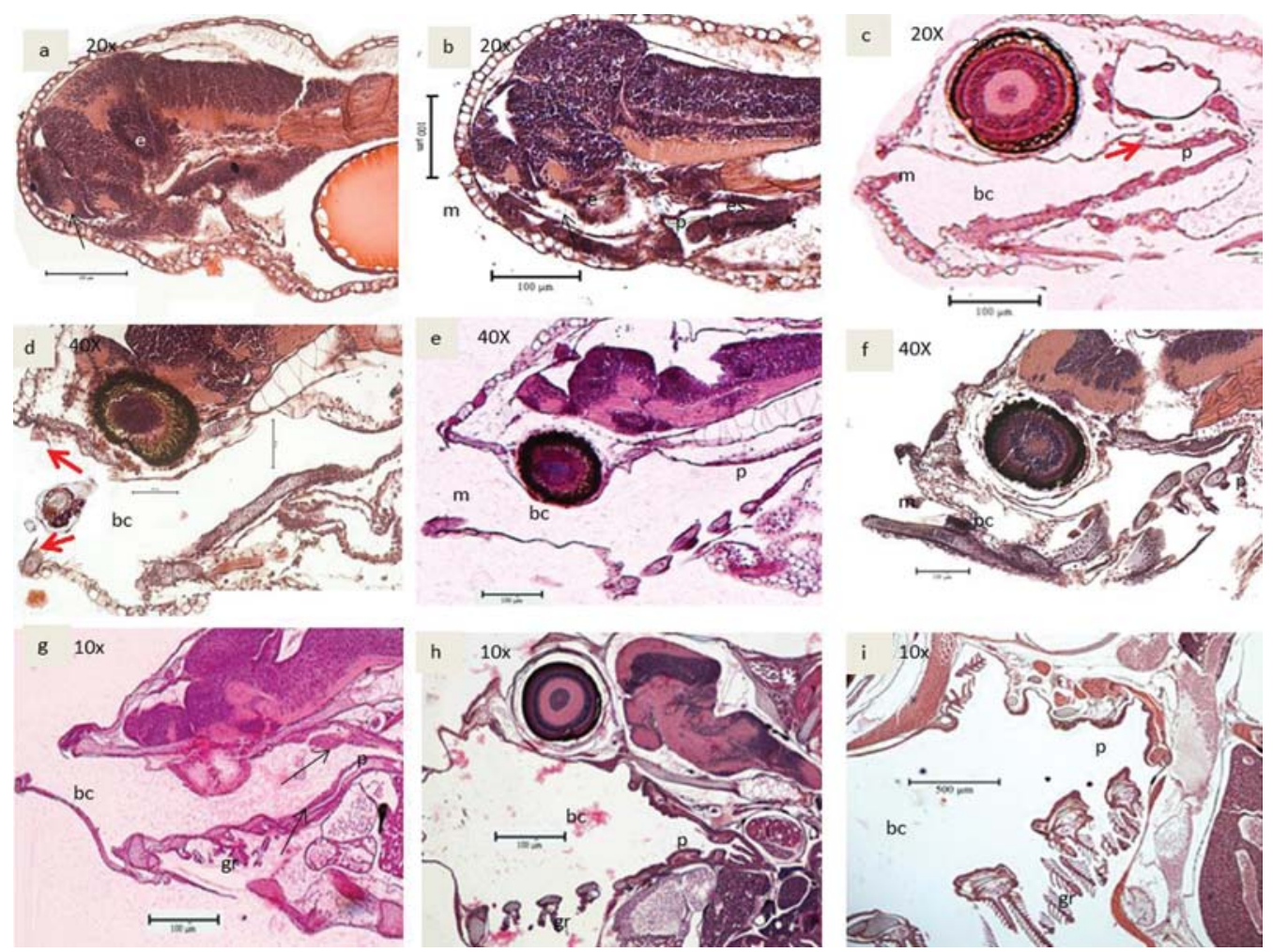

Gambar 1. Irisan melintang perkembangan saluran pencernaan rongga mulut; a. 1 HSM; b. 2 HSM; c. 3 HSM; d. 4 HSM; e. 5 HSM; f. 8 HSM; g. 16 HSM; h. 22 HSM; i. 40 HSM. (m: mulut; bc: buccal cavity; p: paring; gr: gill rake)

Figure 1. Cross section of mouth development; a. 1 DAH; b. 2 DAH; c. $3 D A H ; d .4 D A H ;$ e. $5 D A H$; f. $8 \mathrm{DAH}$; g. $16 \mathrm{DAH}$; h. $22 \mathrm{DAH}$; i. $40 \mathrm{DAH}$. (m: mouth; bc: buccal cavity; p: pharink; gr: gill raker) 
Lidah dibentuk oleh penebalan sederhana dari lantai mulut yang terdiri atas epitel skuamosa bertingkat di wilayah rongga mulut. Pada umur 16 DAH sel goblet tampak di lapisan epitel skuamosa dalam rongga faring. Selain itu, organ insang terlihat dengan jelas. Lamela insang semakin komplek dan berkembang (Gambar 1g). Lapisan epitel pada rongga faring menjadi berlipat-lipat pada umur ini sampai dengan kerongkongan (Gambar 1h). Tulangtulang di sekitar mulut, rongga mulut, dan tekak terlihat lebih tebal dan keras pada 40 HSM (Gambar 1i).

Sel goblet yang merupakan indikator proses pencernaan di kerongkongan berlangsung telah muncul pada umur sekitar 6-7 HSM dan menjadi banyak mulai umur 10 HSM (Gambar 2d). Hal ini juga dikuti dengan semakin berkembangnya lapisan epitel pada kerongkongan dan jumlah sel goblet pada usia 16 HSM (Gambar 2e dan 2f). Semakin dewasa umur larva, jumlah sel goblet ini terus berkembang hingga mencapai usia 35 HSM (Gambar 2 g dan 2h). Pada akhirnya saat larva mencapai stadia yuwana, kerongkongan terlihat hanya tampak seperti saluran pendek yang tipis dan dipenuhi oleh lapisan epitel skuamosa dan sel goblet (Gambar 2i).

Pada umur 1 HSM, perut belum bisa diamati (saluran pencernaan berbentuk lurus dari mulut sampai anus) (Gambar 3a). Perut awal (primordial) awalnya muncul menyerupai tonjolan di ujung kerongkongan pada umur 2 HSM (Gambar 3b) tanda panah. Pada umur 3 HSM, perut mulai tampak membesar dan terlihat jelas di ujung kerongkongan (Gambar 3c). Perut mulai berlipat dan menekan kantong udara (kantong udara pada umur 3 HSM sudah mulai berkembang sehingga membantu larva mengambang) (Gambar 3d). Perut terus mulai berkembang membentuk seperti lapisanlapisan penyekat hingga perut memiliki bagian cardiac dan bagian fundik pada umur 19 HSM (Gambar 3f). Kelenjar perut/lambung mulai muncul pada usia larva 28 HSM (Gambar 3h), kelenjar lambung sangat penting peranannya dalam proses pencernaan di perut. Sekitar umur 30-an organ pyloric caeca yang juga berperan dalam mensekresi enzim-enzim pencernaan (Gambar 3h). Perut bagian belakang (fundik) juga semakin membesar, sedangkan perut bagian cardiac (depan)
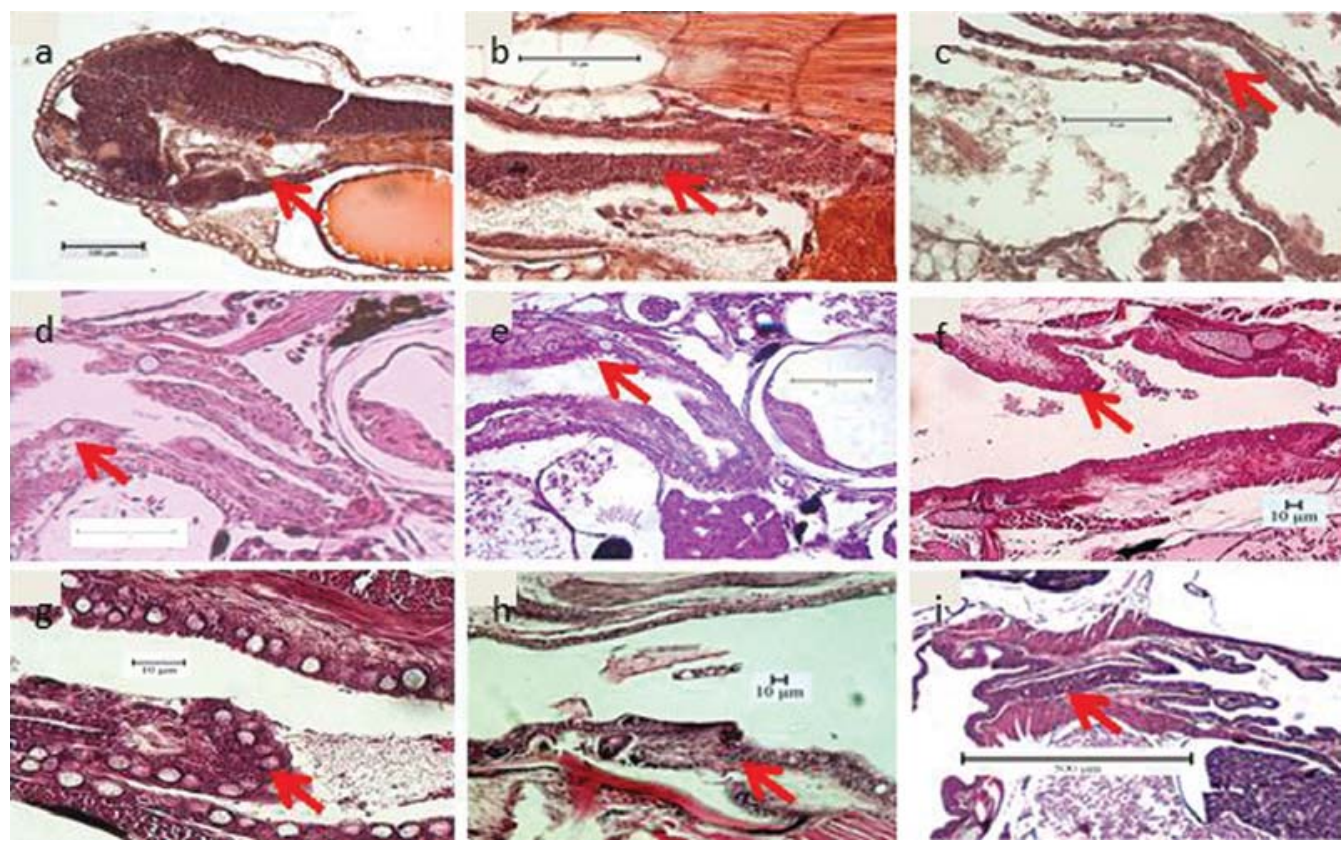

Gambar 2. Irisan melintang perkembangan saluran pencernaan kerongkongan; a. 1 HSM; b. 2 HSM; c. 3 HSM; d. 10 HSM; e. 16 HSM; f. 25 HSM; g. 34 HSM; h. 37 HSM; i. 40 HSM

Figure 2. Cross section of esophagus development; a. 1 DAH; b. 2 DAH; c. 3 DAH; d. $10 \mathrm{DAH}$; e. 16 DAH; f. 25 DAH; g. 34 DAH; h. 37 DAH; i. 40 DAH 

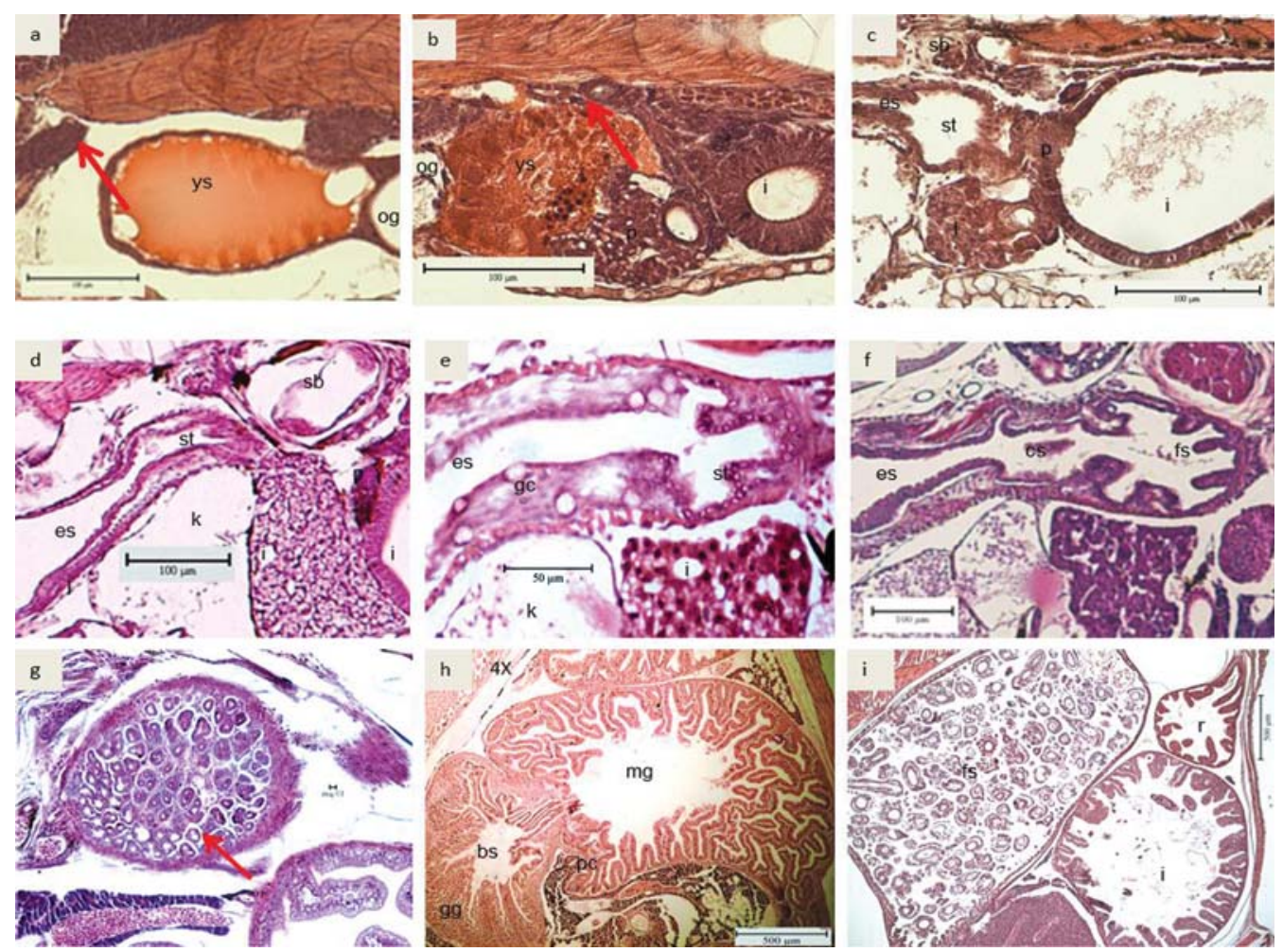

Gambar 3. Irisan melintang perkembangan saluran pencernaan bagian perut; a. 1 HSM; b. 2 HSM; c. 3 HSM; d. 8 HSM; e. 13 HSM; f. 19 HSM; g. 28 HSM; h. 34 HSM; i. 40 HSM. (ys: yolk sac; og: oil globule; p: pancreas; I: liver; i: intestine; es: esophagus; gc: goblet cell; cs: cardiac stomach; fs: fundic stomach; k: kidney; mg: midgut; gg: gastric glands; bs: blind sac; pc: pyloric caeca; r: rectum)

Figure 3. Cross section of stomach development; a. 1 DAH; b. $2 D A H ; c .3 D A H ; d .8 D A H ;$ e. 13 DAH; f. $19 \mathrm{DAH}$; g. $28 \mathrm{DAH}$; h. $34 \mathrm{DAH} ;$ i. $40 \mathrm{DAH}$. (ys: yolk sac; og: oil globule; p: pancreas; I: liver; i: intestine; es: esophagus; gc: goblet cell; cs: cardiac stomach; fs: fundic stomach; k: kidney; mg: midgut; gg: gastric glands; bs: blind sac; pc: pyloric caeca; $r$ : rectum)

terlihat hanya pendek dan seperti corong. Perut bagian fundik inilah yang kemudian menjadi lambung yang berisi banyak makanan untuk dicerna (Gambar 3i). Usus larva kerapu bebek yang baru menetas menyerupai saluran pipa dengan satu lapisan kolumnar sel (Gambar 4a). Pada umur ini usus dan anus masih tertutup. Pada umur 2 HSM, sel-sel epitel berkembang dan meningkat jumlahnya (Gambar 4b). Usus mulai terbuka pada umur 3 HSM bersamaan dengan mulai habisnya cadangan makanan endogen dari yolk sac (Gambar 4c). Pada Gambar 4d terlihat pada umur 5 HSM, sel-sel epitel berkembang dan usus terbagi menjadi 2 bagian yaitu bagian "midgut" dan "hindgut" dan bagian midgut dan hindgut ini terlihat sekali pada umur 7 HSM (Gambar 4e). Pada umur 8 HSM usus mulai berlipat (membentuk fili-fili) dan di antara lipatan-lipatan tersebut mulai muncul lipid vacuola dan achidopilic supranuclear vacuola yang berperan dalam pencernaan protein dan penyerapan makanan di usus (Gambar 4f). Lipatan usus ini berkembang menjadi panjang dan komplek untuk mempermudah penangkap makanan di usus pada 16 HSM (Gambar 4g). Pada usia 22 HSM, goblet sel terdapat muncul pada lipatan-lipatan usus (Gambar 4h), hal ini mengindikasikan adanya proses penyerapan makanan oleh kelenjar yang dihasilkan dari sel-sel ini. Jumlah sel ini masih terlihat sampai dengan usia 40 HSM (Gambar 4i). 

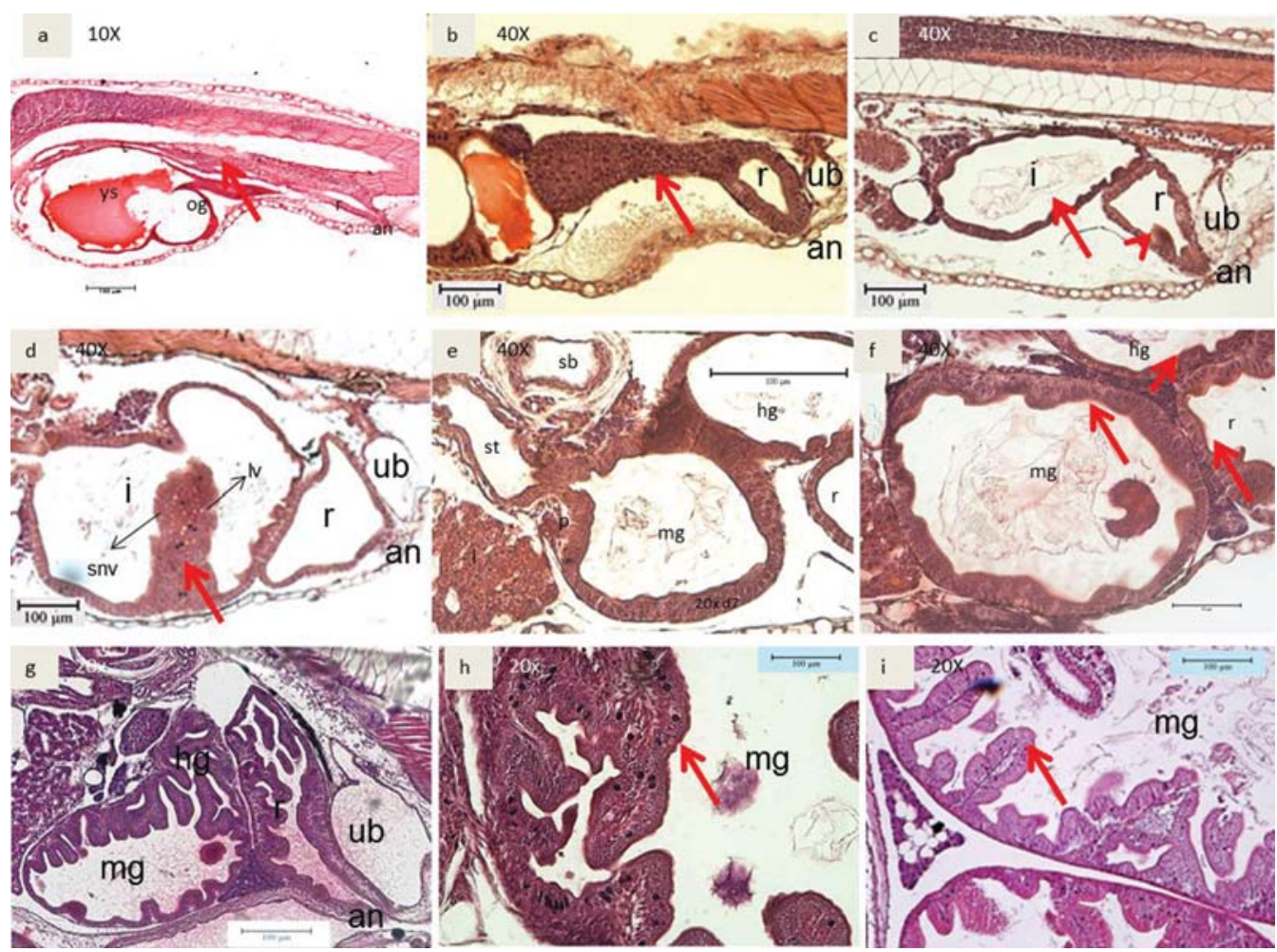

Gambar 4. Irisan melintang perkembangan saluran pencernaan bagian usus; a. 1 HSM; b. 2 HSM; c. 3 HSM; d. 5 HSM; e. 7 HSM; f. 8 HSM; g. 16 HSM; h. 22 HSM; i. 40 HSM. (hg: hindgut; sb: swim bladder, an: anus; ub: urine blader, snv: supranuclear vacuola; Iv: lipid vacuola; ys: yolk sac; og: oil globule; p: pancreas; I: liver; i: intestine; mg: midgut; r: rectum).

Figure 4. Cross section of intestine development; a. $1 \mathrm{DAH}$; b. $2 \mathrm{DAH}$; c. $3 \mathrm{DAH}$; d. $5 \mathrm{DAH}$; e. 7 DAH; f. 8 DAH; g. 16 DAH; h. 22 DAH; i. 40 DAH. (hg: hindgut; sb: swim bladder; an: anus; ub: urine blader; snv: supranuclear vacuole; Iv: lipid vacuole; ys: yolk sac; og: oil globule; $p$ : pancreas; I: liver; $i$ : intestine; $m g$ : midgut; $r$ : rectum)

Hati dan pankreas belum terbentuk sehari setelah menetas (1 HSM). Sejumlah sel basofilik pankreas mulai terbentuk pada umur 2 HSM berdekatan dengan usus baru di antara hati. Hati dan pankreas mulai terbentuk antara umur 2 dan 3 HSM (Gambar 5a) dan sel-sel tersebut meningkat jumlahnya sehingga membentuk hati dan pankreas (Gambar 5b). Kantung empedu mulai muncul di antara hati dan pankreas pada umur 3 HSM (Gambar 5c). Sel darah dan sel sinusoid pada hati telah mulai berkembang pula di kedua organ tersebut (Gambar $5 d$ ). Selain itu, butiran-butiran zimogen juga mulai tampak pada umur ini. Eksokrin pankreas mulai terbentuk pada usia 7 HSM di rongga usus (Gambar 5e). Selain itu, lipid vacuola yang terdapat pada hati terlihat jelas. Pada umur 16 HSM sampai dengan 25 HSM, jumlah hepatosit meningkat pesat dan menunjukkan pula lipid vakuola dan zymogen pada pankreas yang jumlahnya juga meningkat pesat (Gambar $5 f$ dan $5 \mathrm{~g}$ ). Pada 25 HSM, lipid vacuola pada hepatosit sitoplasma terlihat penuh (Gambar $5 \mathrm{~h}$ ). Hal ini terus berlangsung sampai dengan larva mencapai usia yuwana. Ukuran hati dan pankreas menjadi lebih besar dan diikuti oleh semakin banyaknya lipid vakuola pada hati dan zymogen pada pankreas bersamaan dengan kompleksitas dan kuantitas makanan yang dicerna.

\section{Enzim Pencernaan yang Terkait (Tripsin dan Chimotripsin)}

Pola aktivitas enzim tripsin dan kimotripsin pada larva kerapu bebek seperti tampak pada 

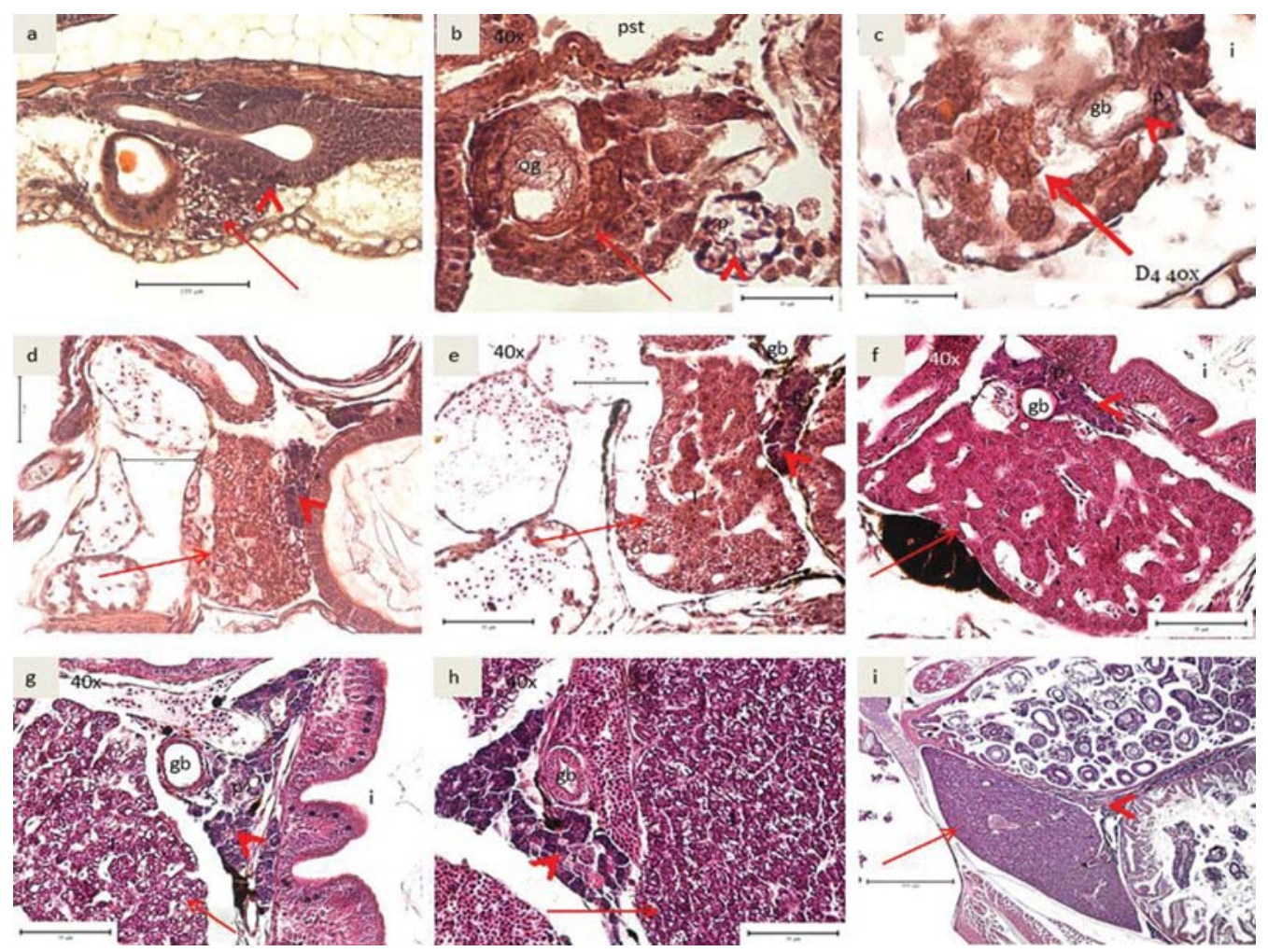

Gambar 5. Irisan melintang perkembangan organ hati dan pankreas; a. 2 HSM; b. 3 HSM; c. 4 HSM; d. 7 HSM; e. 9 HSM; f. 16 HSM; g. 19 HSM; h. 25 HSM; i. 40 HSM. (og: oil globule; pst: primordial stomach; I: liver, p: pancreas; i: intestine; gb: gall bladder)

Figure 5. Cross section of liver and pancreas development; a. $2 \mathrm{DAH} ; b .3 \mathrm{DAH}$; c. $4 \mathrm{DAH} ; \mathrm{d} .7$ DAH; e. 9 DAH; f. 16 DAH; g. 19 DAH; h. 25 DAH; i. 40 DAH. (og: oil globule; pst: primordial stomach; l: liver; $p$ : pancreas; $i$ : intestine; gb: gall bladder).

Gambar 6. Aktivitas tripsin telah terdeteksi pada 1 HSM sebelum yolk sac habis dengan jumlah $0,0835 \mathrm{U} / \mathrm{mg}$ protein. Aktivitas tripsin tidak terlalu berfluktuasi sampai dengan umur 40 HSM. Berbeda dengan aktivitas cimotripsin, pada awal stadia larva, aktivitas cimotripsin telah pula terdeteksi pada 1 HSM dengan jumlah aktivitas yang lebih tinggi yaitu 0,3326 $\mathrm{U} / \mathrm{mg}$ dan berfluktuasi sampai umur $20 \mathrm{HSM}$ kemudian meningkat drastis sampai 0,8228 $\mathrm{U} / \mathrm{mg}$ pada umur 31 HSM. Namun aktivitas cimotripsin kembali turun dan berfluktuasi sampai umur $40 \mathrm{HSM}$.

\section{Bahasan}

Diferensiasi organ pencernaan ikan kerapu bebek turunan ke-3 (F-3) yang diamati dalam penelitian ini secara garis besar hampir sama dengan generasi sebelumnya. Perbedaan waktu diferensiasi organ yang terjadi bisa disebabkan unsur makanan yang diberikan kepada larva atau mungkin faktor genetik. Sebagai contoh penelitian yang telah dilakukan sebelumnya oleh Munafi et al. (2011) dikatakan bahwa gastric gland atau kelenjar lambung terbentuk pada umur 25 HSM namun dalam penelitian ini baru terlihat pada umur 28 HSM. Secara umum, perkembangan organ pencernaan terbagi dalam 3 fase. (Boulhic \& Gabaudan, 1992; Bisbal \& Bengtson, 1995), fase pertama dimulai dari penetasan dan diakhiri pada umur 2 HSM. Pada akhir fase ini mulut terbuka dan perut serta usus telah siap menerima makanan. Pada penelitian ini, sampai dengan umur tiga hari telah terbentuk organorgan pencernaan walaupun belum fungsional secara baik seperti mulut, kerongkongan, lambung, usus, dan anus. Hal ini sama seperti 


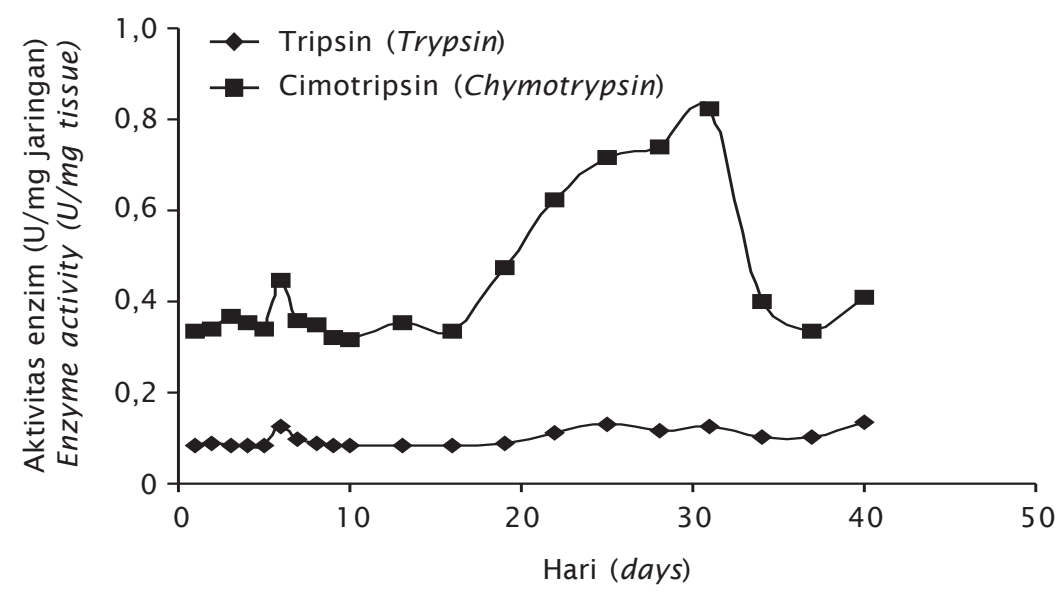

Gambar 6. Grafik kombinasi aktivitas enzim tripsin dan cimotripsin selama pemeliharaan larva kerapu bebek

Figure 6. Combination of trypsin and chymotrypsin enzyme activity during rearing of humpback grouper larvae

penelitian yang telah dilakukan sebelumnya oleh Munafi et al. (2011) pada ikan kerapu bebek F-0 (Cromileptes altivelis), kerapu macan (Epinephelus fuscoguttatus) (Ariza, 2010), kelp grouper (Epinephelus bruneis) (Kato et al., 2004), dusky grouper (Epinephelus marginatus) (Glamuzina et al., 1998), leopard grouper (Mycteroperca rosacea) (Martinez \& Lopez, 2009), dan green grouper (Epinephelus coioides) (Quinitio et al., 2004).

Pada umur 4 HSM, acidophilic supranuclear vakuola mulai terdeteksi, hal ini mengindikasikan telah dimulainya penyerapan protein di dalam usus. Selain itu, juga telah terdeteksi lipid vacuoles pada umur ini. Perubahan struktur usus pada usia 7 sampai 8 HSM hingga terdapat bagian midgut dan hindgut. Watanabe (1984) mengatakan bahwa terdeteksinya supranuclear vacuoles mengindikasikan adanya pinocytosis dan penyerapan protein secara intrasel. Selain itu, adanya lipid vacuoles di usus midgut mengindikasikan kemungkinan penyerapan lemak di usus (Deplano et al., 1991; Sarasquete \& Yufera, 1995; Pena et al., 2003). Fase kedua merupakan fase yang sangat kritis bagi kehidupan larva, karena larva ikan harus memiliki mekanisme adaptasi dalam mencari makan dari luar setelah cadangan makanan endogennya habis (May, 1974). Selama periode ini, larva kerapu bebek mengalami diferensiasi dalam struktur dan fungsi organ pencernaanya untuk dapat mencerna dan menyerap makanan dari luar sebelum habisnya cadangan makanan. Perubahan yang sangat cepat pada organ pencernaan dan kecepatan laju penyerapan yolk sac serta gelembung minyak dapat menyebabkan kelaparan atau malnutrisi jika makanan yang dibutuhkan tidak tersedia (Chen et al., 2006).

Terbentuknya gastric glands dan pyloric caeca merupakan indikator tercapainya fase ketiga (terakhir) dan sebagai tanda telah terjadi perubahan dari stadia larva ke yuwana (Baglole et al., 1997). Pada ikan kerapu bebek F-0 sampai terbentuknya gastric glads (kelenjar lambung) dan pyloric caeca tercapai pada umur 25 HSM (Munafi et al., 2011 ), kemudian 20 HSM pada green grouper (E. coioides) (Quinitio et al., 2004), 26 HSM pada kerapu macan (tiger grouper) (E. fuscoguttatus) (Ariza, 2010). Sedangkan pada penelitian ini, kerapu bebek turunan ke-3 kelenjar lambung mulai terdeteksi pada umur 28 HSM. Hasil ini mengindikasikan diferensiasi larva kerapu bebek turunan ke-3 lebih lambat masuk fase yuwana daripada turunan F-0-nya. Terbentuknya kelenjar lambung ini secara umum bertepatan dengan adanya peningkatan aktivitas enzim pencernaan dan kemampuan mencerna dari larva selama proses metamorfosis menjadi yuwana. Seperti yang dikemukakan Tanaka (1971) dan Stroband \& Dabrowski (1981), fase yuwana dimulai saat kelenjar lambung telah terbentuk dan berkembang, lambung menunjukkan adanya aktivitas penyerapan makanan, 
dan terbentuknya pyloric caeca. Adanya kelenjar lambung menjadi indikator dari telah fungsionalnya perut/lambung (Stroband \& Kroon, 1981). Kelenjar lambung mengindikasikan efisiensi penyerapan makanan, tetapi waktu yang dibutuhkan setiap spesies dalam terbentuknya kelenjar lambung berbeda. Secara umum, informasi diferensiasi organ pencernaan sangat terbatas, apalagi sampai kepada turunan F-2. Dari beberapa informasi di atas dapat digarisbawahi bahwa kelenjar lambung pada spesies kerapu terbentuk sekitar larva umur 20 sampai dengan 30 HSM. Diferensiasi terbentuknya pyloric caeca merupakan indikasi terakhir dari perubahan organ pencernaan dalam larva ikan (Bisbal \& Bengtson, 1995; Hamlin et al., 2000). Hal terpenting dari keseluruhan proses diferensiasi organ ini adalah terjadinya formasi pembentukkan perut bagian fundic, organ ini sangat vital untuk dapat menyimpan makanan yang banyak untuk proses enzimatis dalam penyerapan makanan.

Secara umum aktivitas enzim tripsin dalam penelitian ini lebih rendah dari aktivitas cimotripsin, dan kedua aktivitas enzim tersebut telah terdeteksi saat fase endogenous. Tripsin dan cimotripsin memainkan peranan penting dalam proses penyerapan makanan pada stadia larva. Pada penelitian sebelumnya pada ikan sea bass ( $D$. labrax) tripsin dan cimotripsin juga terdeteksi sebelum terjadinya proses pemanfaatan makanan dari luar (Zambonino-Infante \& Cahu, 1994). Kedua enzim tersebut juga terdeteksi pada proses embriogenensis ikan Atlantic cod sebelum menetas. Hal ini dimungkinkan untuk menjaga agar dapat meningkatkan nilai sintasan larva saat awal pemanfaatan makanan dari luar sehingga menstimulasi aktivitas kedua enzim tersebut (Sveinsdóttir, 2006). Aktivitas secara umum kedua enzim tersebut dari 1 HSM sampai dengan 40 HSM berfluktuasi. Variasi maksimum dari aktivitas enzim alkaline dan acid type proteases, $\alpha$-amylase, lipase, tripsin, cimotripsin, leucine aminopeptidase, acid, dan alkaline phosphatases dalam saluran pencernaan pada larva kerapu sebagian besar berhubungan dengan masa akhir dari metamorfosis larva (Eusebio et al., 2004), dan diferensiasi organ pencernaan (Mcbridge, 2004). Seperti yang dikemukakan oleh Chen et al., 2006, fluktuasi aktivitas enzim menjelaskan adanya diferensiasi pada fase larva, masa perubahan morfologi dalam organ pencernaan dan organ yang terkait. Sebelum lambung dan kelenjar lambung terdiferensiasi, secara umum larva yang bersifat planktonik mencerna makanan dengan menggunakan organ pankreas dan enzim usus (Kurokawa $\&$ Suzuki, 1996; 1998; Anand et al., 2002), dan dengan penyerapan secara intrasel pada bagian depan usus (Tanaka, 1972; Watanabe, 1981 \& 1982). Adanya kecenderungan menurunnya aktivitas kedua enzim pada akhir fase metamorfosis tersebut mengindikasikan bahwa tripsin dan chimotripsin tidak lagi menjadi enzim utama saat sudah masuk stadia yuwana, seperti yang dikatakan oleh Chen et al., 2006. Profil dari kedua enzim pencernaan ini hanya didasarkan pada hubungannya dengan makanan yang kaya akan karbohidrat dan protein. Enzim-enzim yang lain dapat diteliti kembali untuk mengetahui sejauh mana pengaruhnya terhadap larva ikan kerapu bebek seperti aktivitas enzim proteolitik dan amylase di mana kontribusi dari keduanya belum diketahui dalam penelitian ini.

\section{KESIMPULAN}

Fase yuwana kerapu bebek turunan ketiga (F-3) tercapai lebih lambat daripada larva kerapu bebek dari penelitian sebelumnya yang menggunakan larva hasil pembenihan F-0 yang diberi pengkayaan pakan. Hal ini ditunjukkan dengan terbentuknya "gastric gland" dan "pyloric caeca" sebagai indikator saluran pencernaan berfungsi dengan baik baru terjadi pada umur 28 HSM. Enzim pencernaan (tripsin dan chimotripsin) sudah terdeteksi pada 1 HSM.

\section{UCAPAN TERIMA KASIH}

Sebagai bagian lain dari makalah ini, kami sampaikan terima kasih yang sebesarbesarnya kepada Bpk. Ir. Tridjoko, M.S. atas fasilitas telur hasil pemijahan induk F-2 dan Bpk. I Gusti Bagus Winaya yang telah membantu penanganan telur di lapangan, Bpk. I Nyoman Restiada dan Bpk. Muhdiat yang telah membantu dalam penyediaan pakan alami, dan juga Bpk. Mujimin yang telah membantu dalam penyiapan sampel untuk histologinya.

\section{DAFTAR ACUAN}

Anand, S., Kurokawa, T., \& Suzuki, T. 2002. mRNA expression of pancreatic enzyme precursors and estimation of protein digestibility in first feeding larvae of Japanese flounder, Paralichthys olivaceus. Comp. Biochem. Physiol. Part A, 132: 629-635. 
Ariza, S.A. 2010. Ontogenetic Digestive System and Enzyme Activity in Early Life of Tiger Grouper Epinephelus fuscoguttatus, Thesis of Master of Science. Universiti Malaysia Terengganu. Unpublished, $113 \mathrm{hlm}$.

Baglole, C.J., Murray, H.M., Goff, G.P., \& Wright, G.M. 1997. Ontogeny of the digestive tract during larval development of yellowtail flounder: a light microscopic and mucous histochemical study. J. Fish Biol., 51: 120134.

Bisbal, G.A. \& Bengtson, D.A. 1995. Development of the digestive tract in larval summer flounder. J. Fish Biol., 47: 277-291.

Boulhic, M. \& Gabaudan, J. 1992. Histological study of the organogenesis of the digestive system and swim bladder of the Dover sole, Solea solea (Linnaeus 1758). Aquaculture, 102: 373-396.

Buddington, R.K. 1985. Digestive secretions of lake sturgeon, Acipenser fulvescens, during early development. Journal of Fish Biology, 26: 71 5-723.

Cahu, C. \& Zambonino-Infante, J. 2001. Substitution of live food by formulated diets in marine fish larvae. Aquaculture, 200: 161180.

Canino, M.F. \& Bailey, K.M. 1995. Gut evacuation of walleye Pollock larvae in response to feeding conditions. J. Fish Biol., 46: 389403.

Chen, B.N., Qin, J.G., Kumar, M.S., Hutchinson, W., \& Clarke, S. 2006. Ontogenetic development of the digestive system in yellowtail kingfish, Seriola lalandi larvae. Aquaculture, 256: 489-501.

Deplano, M., Diaz, J.P., Connes, R., KentouriDivanach, M., \& Cavalier, F. 1991. Appearance of lipid-absorption capacities in larvae of the sea bass Dicentrarchus labrax during transition to the exotrophic phase. Mar. Biol., 108: 361-371.

Drury, R.A. \& Wallington, E.A. 1967. Carleton's Histological Technique, $4^{\text {th }}$ edition. Oxford: Oxford University Press, $432 \mathrm{hlm}$.

Erlanger, B.F., Kokowski, N., \& Cohen, W. 1961. The preparation and properties of two new chromogenic substrates of trypsin. Arch. Biochem. Biophys., 95: 271-278.

Eusebio, P.S., Toledo, J.D., Mamauag, R.E.P., \& Bernas, M.J.G. 2004. Digestive enzyme activity in developing grouper (Epinephelus coioides) larvae. In Rimmer, M.A., McBride, S., \& Williams, K.C. (Eds.). Advances in grouper aquaculture: Australian Center for International Agriculture Research, Canberra, p. 35-40.

Giri, N.A., Suwirya; K., \& Marzuqi, M. 2006. Observation on Gonad Maturation of the First Generation ( $\mathrm{F}-1$ ) of Humpback Grouper, Cromileptes altivelis. Indonesian Aquaculture Journal, 1(2): 79-86.

Glamuzina, B., Skaramuca, B., Glavic, N., Kozul, V., Dulcic, J., \& Kraljevic, M. 1998. Egg and early larval development of laboratory reared dusky grouper, Epinephelus marginatus (Lowe, 1834) (Picies, Serranidae). Scientia Marina, 62(4): 373378.

Govoni, J.J., Boehlert, G.W., \& Watanabe, Y. 1986. The physiology of digestion in fish larvae. Env. Biol. Fish., 16: 59-77.

Govoni, J.J. 2004. The development of form and function in fishes and the question of larval adaptation. In Govoni, J.J. (Ed.) The Development of Form and Function in Fishes and the Question of Larval Adaptation. American Fisheries Society Symposium, Bethesda, Maryland, 40: 1-7.

Hamlin, H.J., Hunt von Herbing, I., \& King, L.J. 2000. Histological and morphological evaluations of the digestive tract and associated organs of haddock through out post hatching ontogeny. doi:10.1006/ jfbi.2000.1347, Journal of Fish Biology, 57: 716-732.

Kato, K., Ishimaru, K., Sawada, Y., Mutsuro, J., Miyashita, S., Murata., O., \& Kumai, H. 2004. Ontogeny of digestive and immune system organs of larval and juvenile kelp grouper Epinephelus bruneus reared in the laboratory. Fisheries Science, 70: 1,061-1,069.

Kiernan, J.K. 1990. Histological and Histochemical Methods theory and practice. Second edition. Pergamon Press plc., 433 pp.

Kjorsvik, E., Pittman, K., \& Pavlov, D. 2004. From fertilisation to the end of metamorphosisfunctional development. In Moksness, E., Kjorsvik, E., \& Olsen, Y. (Eds.) Culture of Cold-Water Marine Fish. Blackwell Publishing, Carlton, Victoria, p. 204-278.

Kohno, H., Ordonio-Aguilar, R.S., Ohno, A., \& Taki, Y. 1997. Why is grouper larval rearing difficult?: an approach from the development of the feeding apparatus in early stage larvaeof the grouper, Epinephelus coioides. Ichthyological Research, 44: 267274. 
Kurokawa, T. \& Suzuki, T. 1996. Formation of the diffuse pancreas and the development of digestive enzyme synthesis in larvae of the Japanese flounder Paralichthys olivaceus. Aquaculture, 141: 267-276.

Kurokawa, T., Shiraishi, M., \& Suzuki, T. 1998. Quantification of exogenous protease derived from zooplankton in the intestine of Japanese sardine (Sardinops melanotictus) larvae. Aquaculture, 161: 491-499.

Martinez-Lagos, R. \& Gracia-Lopez, V. 2009. Morphological development and growth patterns of the leopard grouper Mycteroperca rosacea during larval development. Aquaculture Research, 41: 120128.

May, R.C. 1974. Larval mortality in marine fishes and the critical period concept. In Blaxter, J.H.S. (Ed.) The Early Life History of Fish. Conference: International Symposium on the Early Life History of Fish. Springer, Berlin, p. 3-19.

McBride, S., 2004. The activity of digestive enzymes in larval grouper and live food. In Rimmer, M.A., McBride, S., \& Williams, K.C. (Eds.). Advances in grouper aquaculture: Australian Center for International Agriculture Research, Canberra, p. 41-46.

Munafi, A.A.B., Andriyanto, W., Ismi, S., Nirmala, A.Y., Mastuti, I., Muzaki, A., \& Effendy, A.W.M. 2011 . The Ontogeny of the Digestive Tract and Associated Organs of Humpback Grouper (Cromileptes altivelis) Larvae. Asian Fisheries Science, 24: 379-386.

Ordonio-Aguilar, R. 1995. Survival Mechanisms of Tropical Marine Fish Larvae During Change over from Endogenous to Exogenous Feeding. PhD Thesis. Tokyo University of Fisheries, Tokyo, Japan, 322 pp.

Pedersen, B.H. \& Hjelmeland, K. 1988. Fate of trypsin and assimilation efficiency in larval herring (Clupea harengus) following digestion of copepods, Mar. Biol., 97: 467476.

Pena, R., Dumas, S., Villalejo-Fuerte, M., \& OrtizGalindo, J.L. 2003. Ontogenetic development of the digestive tract in reared spotted sand bass Paralabrax maculatofasciatus larvae. Aquaculture, 219: 633-644.

Quinitio, G.F., Sa-an, A.C., Toledo, J.D., \& TanFermin, J.D. 2004. Advances in Grouper Acquaculture Edited by Rimmer, M.A., McBride, S., \& Williams, K.C. ACIAR Monograph 110 (printed version), p. 26-29.
Ribeiro, L., Zambonino-Infante, J.L., Cahu, C., \& Dinis, M.T. 1999. Development of digestive enzymes in larvae of Solea senegalensis, Kaup 1858. Aquaculture, 179: 465-473.

Sarasquete, A.P. \& Yufera, M. 1995. Histology and histochemistry of the development of the digestive system of larval gilthead seabream, Sparus aurata L., Aquaculture, 130: 79-92.

Segner, H., Roesch, R., Verreth, J., \& Witt, U. 1993. Larval nutritional physiology: studies with Clarias gariepinus, Coregonus lavaretus and Scophthalmus maximus. J. World Aquac. Soc., 24: 121-134.

Segner, H., Storch, V., Reinecke, M., Kloas, W., \& Hanke, W. 1994. The development of functional digestive and metabolic organs in turbot, Scophthalmus maximus. Mar. Biol., 119: 471-486.

Stroband, H.W.J. \& Dabrowski, K.R. 1981. Morphological and physiological aspects of digestive system and feeding in freshwater fish larvae. In Nutrition des Poissons, Fontain, M. (Ed.) Centre National de la Rechereche Scientifique. Paris, p. 355-374.

Stroband, H.W.J. \& Kroon A.G. 1981. The development of the stomach in Clarias lazera and the intestinal absorption ofprotein macromolecules. Cell Tissue Res., 215: 397415.

Sveinsdóttir, H., Thorarensen, H., \& Gudmundsdóttir, A. 2006. Involvement of trypsin and chymotrypsin activities in Atlantic cod (Gadus morhua) embryogenesis. Aquaculture, 260: 307-314.

Tanaka, M. 1971. Studies on the structure and function of the digestive system in teleost larvae: III. Development of the digestive system during postlarval stage. Japan J. Ichthyol., 18: 164-174.

Tanaka, M. 1972. Studies on the structure and function of the digestive system in teleost larvae-IV Epithelial change in the posterior-gut and protein ingestion. Japan J. Ichthyol., 19: 172-180. (in Japanese with English summary).

Timeyko, V.N. \& Novikov, G.G. 1987. Proteolyticactivity in the digestive tract of Atlantic salmon, Salmon salar, during larval development. Journal of Ichthyology, 27: 27-33.

Tridjoko \& Haryanti. 2010. Penelitian Calon Induk Kerapu Bebek Turunan Ke-2 (F-2) dan Hasil Tangkapan dari Laut (F-0). Prosiding 
Simposium Nasional Pembangunan Sektor Kelautan dan Perikanan Kawasan Timur Indonesia, hlm. 230-237.

Tridjoko \& Gunawan. 2010. Pengamatan Diameter Sel Telur Calon Induk Ikan Kerapu Bebek (Cromileptes altivelis) Turunan Kedua (F-2) dalam Menunjang Teknologi Pembenihan Ikan Kerapu. Prosiding Forum Inovasi Teknologi Akuakultur. Pusat Riset Perikanan Budidaya, Jakarta, hlm. 605-610.

Tridjoko. 2010a. Keragaan Reproduksi Ikan Kerapu Bebek (Cromileptes altivelis) dari Alam (F-0) Induk Generasi Pertama (F-1) dan Induk Generasi Kedua (F-2). Jurnal IImu dan Teknologi Kelautan Tropis, 2(2): 17.

Tridjoko. 2010 b. Pemijahan Induk Ikan Kerapu Bebek (Cromileptes altivelis) Generasi Ke2 (F-2) dalam Menunjang Teknologi Pembenihan Ikan Laut. Prosiding Seminar Nasional Tahunan VII Hasil Penelitian Perikanan dan Kelautan, 24 Juli 2010. pp; GN 07.

Tridjoko. 2008. Reproduksi Induk Ikan Kerapu Bebek (Cromileptes altivelis) dari Hasil Tangkapan di Laut (F-0) dan Hasil Budidaya (F-1) yang Dipelihara dalam Bak Secara Terkontrol. Prosiding Seminar Nasional Biodiversitas II Buku 2. Universitas Airlangga. Surabaya, hlm. 193.

Tridjoko, Haryanti, \& Muzaki, A. 2008. Keragaan Induk Ikan Kerapu Bebek (F-1) dari Hasil Seleksi. Prosiding Seminar Nasional Kelautan IV Optimalisasi Pembangunan Kelautan Berbasis Iptek dalam Rangka Peningkatan Kesejahteraan Masyarakat Maritim. Universitas Hang Tuah, Surabaya, hlm. 1-125.

Tridjoko. 2007. Penggunaan ikan Kerapu Bebek (Cromileptes altivelis) hasil Budidaya ( $\mathrm{F}-1$ ) sebagai salah satu alternatif sumber induk. Prosiding Seminar Nasional Kelautan III Pembangunan Kelautan Berbasis Iptek dalam Rangka Peningkatan Kesejahteraan Masyarakat Pesisir. Universitas Hang Tuah, Surabaya, hlm. 1.
Tridjoko, Setiadi, E., Ismi, S., \& Johnny, F. 2006. Observation on Gonad Maturation of The First Generation (F-1) of Humpback Grouper, Cromileptes altivelis. Indonesian Aquaculture Journal, 1(2): 97-103.

Tridjoko, \& Prijono, A. 2011 . Pengaruh Hormon $17 \alpha$ Methyltestoteron (MT) Terhadap Perubahan Sex Kelamin Pada Ikan Kerapu Bebek (Cromileptes altivelis) Turunan Ke-2 (F-2). Prosiding Seminar Nasional Tahunan VIII Hasil Penelitian Perikanan dan Kelautan Jilid I, Budidaya Perikanan. pp; GN 01.

Ueberschär, B. 1995. The use of tryptic enzyme activity measurement as a nutritional condition index: laboratory calibration data and field application. ICES Marine Science Symposium, 201: 119-129.

Watanabe, Y. 1981. Ingestion of horseradish peroxidase by the intestinal cells in larvae or juveniles of some teleosts. Bull. Jph. Soc. Sci. Fish., 47: 1,299-1,307.

Watanabe, Y. 1982. Intracellular digestion of horseradish peroxidase by the intestinal cells of teleost larvae and juvenile. Bull. Jpn. Soc. Sci. Fish., 48: 37-42.

Watanabe, Y. 1984. Morphological and functional changes in rectal epithelium cells of pond smelt during postembryonic development. Bull. Jpn. Soc. Sci. Fish., 50: 805814.

Watanabe, T. \& Kiron, V. 1994. Prospects in larval fish dietetics. Aquaculture, 124: 223 251.

Zambonino-Infante, J.L. \& Cahu, C.L. 1994. Development and response to a diet change of some digestive enzymes in sea bass (Dicentrarchus labrax) larvae. Fish Physiology and Biochemistry, 12: 399-408.

Zambonino-Infante, J.L. \& Cahu, C.L. 2001 . Ontogeny of the gastrointestinal tract of marine fish larvae. Comp. Biochem. Physiol., 130C: 477-487. 